\title{
Geographic variation of Microtus middendorffii (Cricetidae, Arvicolinae, Rodentia) sensu lato studied by craniometrical and mitochondrial features
}

\author{
Andrey A. Lissovsky, Ekaterina V. Obolenskaya, Natalia I. Abramson, \\ Nikolai E. Dokuchaev, Valeriy V. Yakimenko, Marina G. Mal'kova, \\ Alexey S. Bogdanov \& Natalia V. Ivanova
}

\begin{abstract}
Morphometric variation of voles Microtus middendorffii sensu lato and M. gromovi was examined based on 221 skulls. Molecular variation was assessed on partial sequences of cytochrome C oxidase subunit I gene $(657 \mathrm{bp})$ from 23 individuals of $M$. middendorffii s.l. The observed pattern of variation within $M$. middendorffii s.l. corresponds to polytypic species comprising a number of geographic races. The taxonomic rank of the Ural and Yamal race (M. m. ryphaeus) is not lower than the rank of $M$. $m$. middendorffii and $M . m$. hyperboreus. Essential morphological differences within the scope of this study were found for the sample from the Kochechum River. The voles of M. gromovi are very similar morphologically to $M$. middendorffii. Taxa M. middendorffii, M. gromovi, and M. mongolicus form the single clade on the mitochondrial based tree, with $M$. gromovi as a basal taxon.
\end{abstract}

KEY WORDS: Microtus middendorffii, Microtus hyperboreus, Microtus gromovi, geographic variation.

AndreyA.Lissovsky [andlis@zmmu.msu.ru] and EkaterinaV.Obolenskaya [obolenskaya@zmmu.msu.ru],Zoological Museum of Moscow State University, Bolshaya Nikitskaya 6, Moscow 125009, Russia; Natalia I. Abramson [lemmus@zin.ru], Zoological Institute, Russian Academy of Sciences, Universitetskaya nab. 1, Saint Petersburg 199034, Russia; Nikolai E. Dokuchaev [dokuchaev@ibpn.kolyma.ru], Institute of Biological Problems of the North, Far East Branch of the Russian Academy of Sciences, ul. Portovaya 18, Magadan 685000, Russia; Valeriy V. Yakimenko[vyakimenko78@yandex.ru] and Marina G. Mal'kova, Omsk scientific-research institute of naturel-foci infections, Mira prospekt 7, Omsk 644080,Russia; Alexey S. Bogdanov [bogdalst@yahoo.com], Koltzov Institute of Developmental Biology, Vavilova 26, Moscow 119991, Russia; Natalia V. Ivanova [nivanova@uoguelph.ca], Biodiversity Institute of Ontario, University of Guelph, Guelph, Ontario, Canada N1G 2W1.

\section{Географическая изменчивость краниометрических и митохондриальных признаков Microtus middendorffii (Cricetidae, Arvicolinae, Rodentia) sensu lato}

\author{
А.А. Лисовский, Е.В. Оболенская, Н.И. Абрамсон, Н.Е. Докучаев, \\ В.В. Якименко, М.Г. Малькова, А.С. Богданов, Н.В. Иванова
}

РЕЗЮМЕ. Исследована выборка из 221 черепа представителей Microtus middendorffii sensu lato и $M$. gromovi. Генетические данные по участку гена цитохром Ц оксидазы (657 пар оснований) получены от 23 экземпляров $M$. middendorffii s.1. Наблюдаемая картина изменчивости внутри M. middendorffii s.1. более всего соответствует политипическому виду, представленному несколькими географическими формами. Ранг урало-ямальской формы (M. m. ryphaeus) не ниже, чем M. m. middendorffii и M. m. hyperboreus. Сушественные, в масштабе исследования, морфологические отличия характеризуют выборку с р. Кочечум. Морфологически представители M. gromovi очень близки к M. middendorffii. Таксоны M. middendorffi, M. gromovi и M. mongolicus образуют единую кладу на митохондриальном дереве, базальное положение в этой кладе занимает M. gromovi.

КЛЮЧЕВЫЕ СЛОВА: Microtus middendorffii, Microtus hyperboreus, Microtus gromovi, географическая изменчивость. 


\section{Introduction}

Debates on the taxonomic status of the Middendorff's vole (Microtus middendorffii Poljakov, 1881) and the north Siberian vole (M. hyperboreus Vinogradov, 1933) have a long history. It was reviewed in detail earlier (Meyer et al., 1996; Litvinov, 2001; Volpert \& Shadrina, 2002). The study comparing all previous opinions is, however, still absent. This makes the discussed concepts ambiguous and unreliable.

The discussion always focused on the species or subspecies rank of $M$. hyperboreus. The other taxa, mentioned from time to time, were classified a priori either to $M$. m. middendorffii, or to $M$. m. hyperboreus.

Morphological characters differentiating $M . m$. middendorffii and $M . m$. hyperboreus are described in a number of publications (Vinogradov, 1933; Ognev, 1950; Vinogradov \& Gromov, 1952; Krivosheev, 1971; Pokrovskiy et al., 1975; Gromov \& Polyakov, 1977; Meyer et al., 1996; Litvinov, 2001). Following these descriptions, different authors separated $M$. m. middendorffii from $M . m$. hyperboreus in collections. But it is impossible to find two publications where the composition of taxa distinguished on the base of the same characters would coincide (Ognev, 1950; Krivosheev, 1971; Gromov \& Polyakov, 1977; Meyer et al., 1996; Litvinov, 2001; Volpert \& Shadrina, 2002). In other words, different authors starting from the same points referred the same specimens to different taxa. Therefore, the morphological variation of $M$. middendorffii sensu lato needs quantitative evaluation.

Another issue, which has not been addressed yet, is the morphological distinctiveness of $M$. gromovi Vorontsov et al., 1988. As inferred from the data on cytochrome $b$ gene (Bannikova et al., 2010) and the general habitus of this vole, it is very close to $M$. middendorffii. It is, therefore, important to evaluate the morphological similarity between these two species and estimate the probability of their morphological misidentification.

Thus, the main task of the present study is to give a quantitative estimation of variation in $M$. middendorffii s.l. and $M$. gromovi. We intentionally avoid discussing the nomenclatorial questions here and will use the established names.

\section{Materials and methods}

Specimens used in the morphometric study were taken from the collections of the Zoological Museum of Moscow State University (ZMMU), Zoological Institute of the Russian Academy of Science, St-Petersburg (ZIN), Institute of Systematics and Ecology of Animals, Siberian Branch of the Russian Academy of Science (ISEA), Institute of Plant and Animal Ecology, Ural Branch of the Russian Academy of Science (IPAE), Institute of Biological Problems of North, Far East Branch of the Russian Academy of Science (IBPN).
The sample contained 221 intact skulls of M. middendorffii s.l. and M. gromovi (Appendix I).

Fifteen measurements were taken with electronic caliper (with an accuracy of $0.01 \mathrm{~mm}$ ) from each skull as follows: condylobasal length, minimal distance between maxillary toothrows, diastemal length, alveolar length of maxillary toothrow, zygomatic breadth, maximal width between lateral edges of auditory bullae, skull height at the level of maxillary toothrows, orbital length and width, width of rostrum' base, orbital constriction, length of auditory bulla, width of auditory bulla, alveolar length of mandibular toothrow, distance between the base of incisor and the apex of mandibular articular process. All calculations were performed based on logarithmic measurements.

We used the skulls of voles of different ages. All skulls were divided into three age categories (Lissovsky \& Obolenskaya, 2010) corresponded to obviously juvenile (1), obviously adult with developed crests on the skull (3), and all others (2).

We used hierarchical two-factor MANOVA with geographical sample and sex treated as factors (sex nested in sample), in order to evaluate significance of differences between sexes. For this purpose we studied five samples of individuals from age group 2 with approximately equal ratio of males and females.

In order to exclude age bias from morphometric analysis, we used an orthogonal projection of initial data along the vector of age variation (Burnaby, 1966). The vector of age variation was calculated as the first eigenvector of the between-group covariance matrix. We used only the first and the third age classes during calculations of the covariance matrix in order to avoid an error induced by inaccuracy in determining the second age class. There were seven samples included in this analysis.

The samples for hierarchical cluster analysis included only specimens collected in the same locality (44 samples total). Only samples with $n>3$ were used in cluster analysis (20 samples). Cluster analysis was performed on the basis of a matrix of Mahalanobis distances using the unweighted pair group method with arithmetic mean (UPGMA). The bias induced by using samples of different sizes was corrected (Marcus, 1993).

An analysis of posterior probabilities was performed using canonical discriminant analysis. The learning sample was composed of specimens used in cluster analysis and divided into groups according to its result.

The ordination was performed using the axes of canonical space calculated with grouping variable containing geographical samples with $n>3$.

Craniometric data were processed using standard modules of STATISTICA 8.0 (StatSoft 2007) and several custom algorithms written by the first author using Statistica Visual Basic programming language.

A fragment of mitochondrial gene cytochrome oxidase subunit 1 (COI) 657bp in length from 23 specimens of $M$. middendorffii s.l. from 8 geographical localities (Appendix II) was used for the study of genetic 


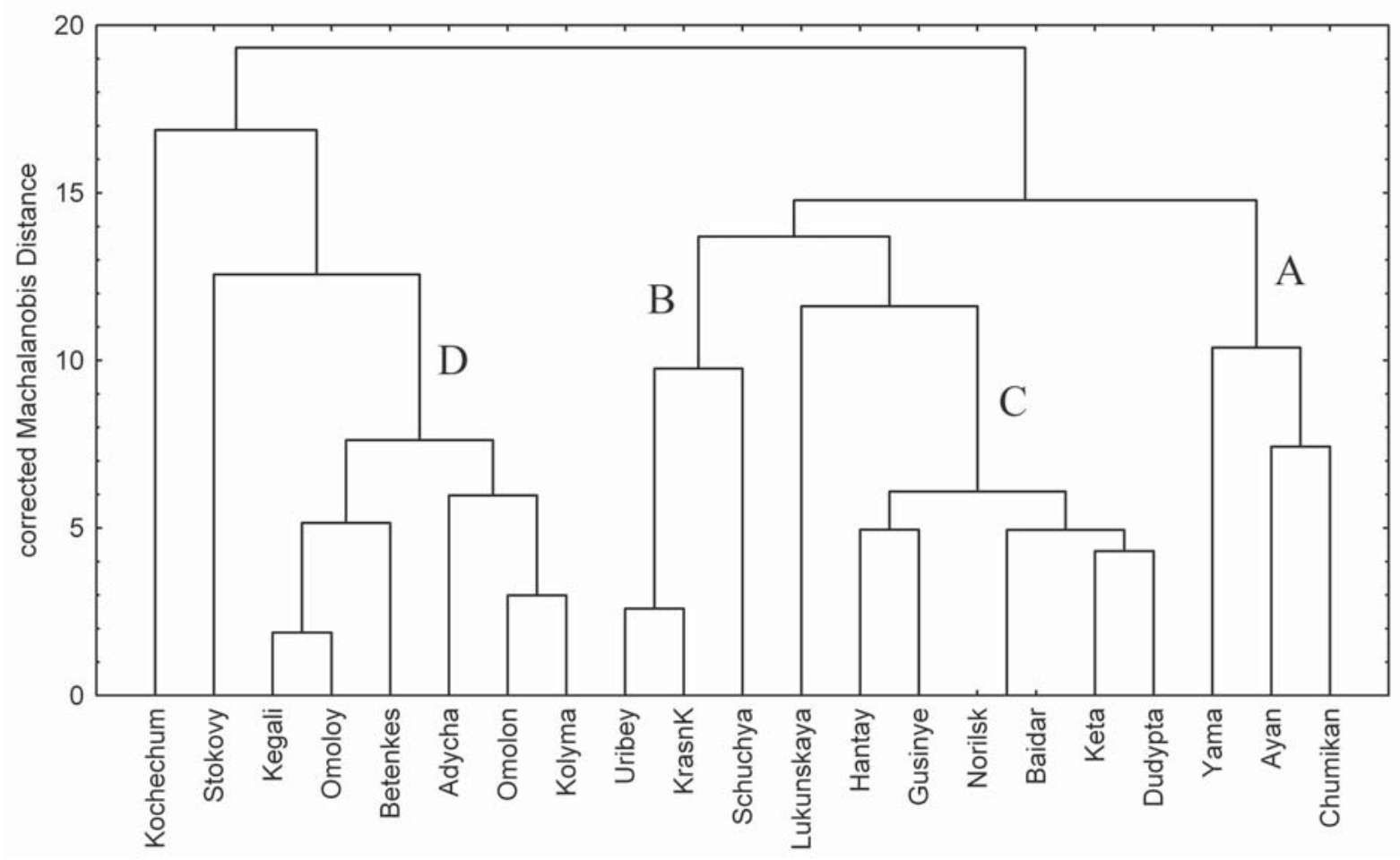

Figure 1. The dendrogram showing results of hierarchical cluster analysis of craniometric features of Microtus middendorffii s.l. and M. gromovi samples. For explanations of sample labels, refer to Appendix I.

differentiation. Analysis also included four specimens of $M$. gromovi from two localities and two specimens of M. mongolicus Radde, 1861 from one locality.

The specimens of $M$. fortis Büchner, 1889 and $M$. maximowiczii Schrenk, 1859, which together with previous species constitute the subgenus Alexandromys (Bannikova et al., 2010), were taken as an outgroup.

In specimens with lack of BOLD number in Appendix II, the gene region was amplified by PCR with the forward/reverse primer combination: TGT AAA ACG ACG GCC AGT TCT CAA CCA AYC AYA ARG AYA TYG G / CAG GAA ACA GCT ATG ACT ARA CTT CTG GRT GKC CRA ARA AYC A. Doublestranded polymerase chain reaction (PCR) usually entailed 30 thermal cycles as follows: $30 \mathrm{~s}$ denaturation at $95^{\circ} \mathrm{C}, 30 \mathrm{~s}$ annealing at $50^{\circ} \mathrm{C}$ and $50 \mathrm{~s}$ extension at $72^{\circ} \mathrm{C}$. All PCR experiments included negative controls. PCR products were visualized on $1.5 \%$ agarose gel and then purified using Omnix DNA purification kit. Approximately 10-30 ng of the purified PCR product was used for sequencing with each primer by auto sequencing system 3730 DNA Analyzer (Applied Biosystems, Foster City, CA, USA) using ABI PRISMR BigDyeT Terminator v. 3.1.

Phylogenetic reconstruction was performed using a maximum likelihood (ML) algorithm. The selection of substitution model, phylogenetic tree reconstructions and genetic distances calculations were performed in Treefinder (Jobb, 2008). The robustness of the trees was assessed by bootstrap resampling (500 replications). Average intergroup genetic distances were calculated in MEGA version 4 (Tamura et al., 2007).

\section{Results}

Sexual dimorphism in the studied samples does not significantly differ from zero (Wilk's Lambda $=0.04, \mathrm{p}$ $=0.08$ ).

Hierarchical cluster analysis distinguishes several groups within the studied sample (Fig. 1). The first one includes three samples from the coast of the Sea of Okhotsk (cluster A). The second includes three samples from the Polar Ural Mts and Yamal Peninsula (cluster B). The third group unites samples from Taimyr Peninsula and one sample from the coast of Baidaratskaya Bay (cluster $\mathrm{C}$ ). The sample from the right bank of the Khatanga River ("Lukunskaya") is adjacent to the cluster $\mathrm{C}$, although it is separated from the latter by quite a large distance. The fourth group consists of samples from Verkhoyansk region, Omolon River and the upper stream of the Kolyma River (cluster D). The sample from the source of Kolyma River ("Stokovy") joins this cluster, but at a considerable distance. The sample from Kochechum River notably differs from all the rest.

The location of groups mentioned above in the ordination plane is shown at the Fig. 2. The distribution of the specimens in the space of several skull measurements is given at the Fig. 3 . 


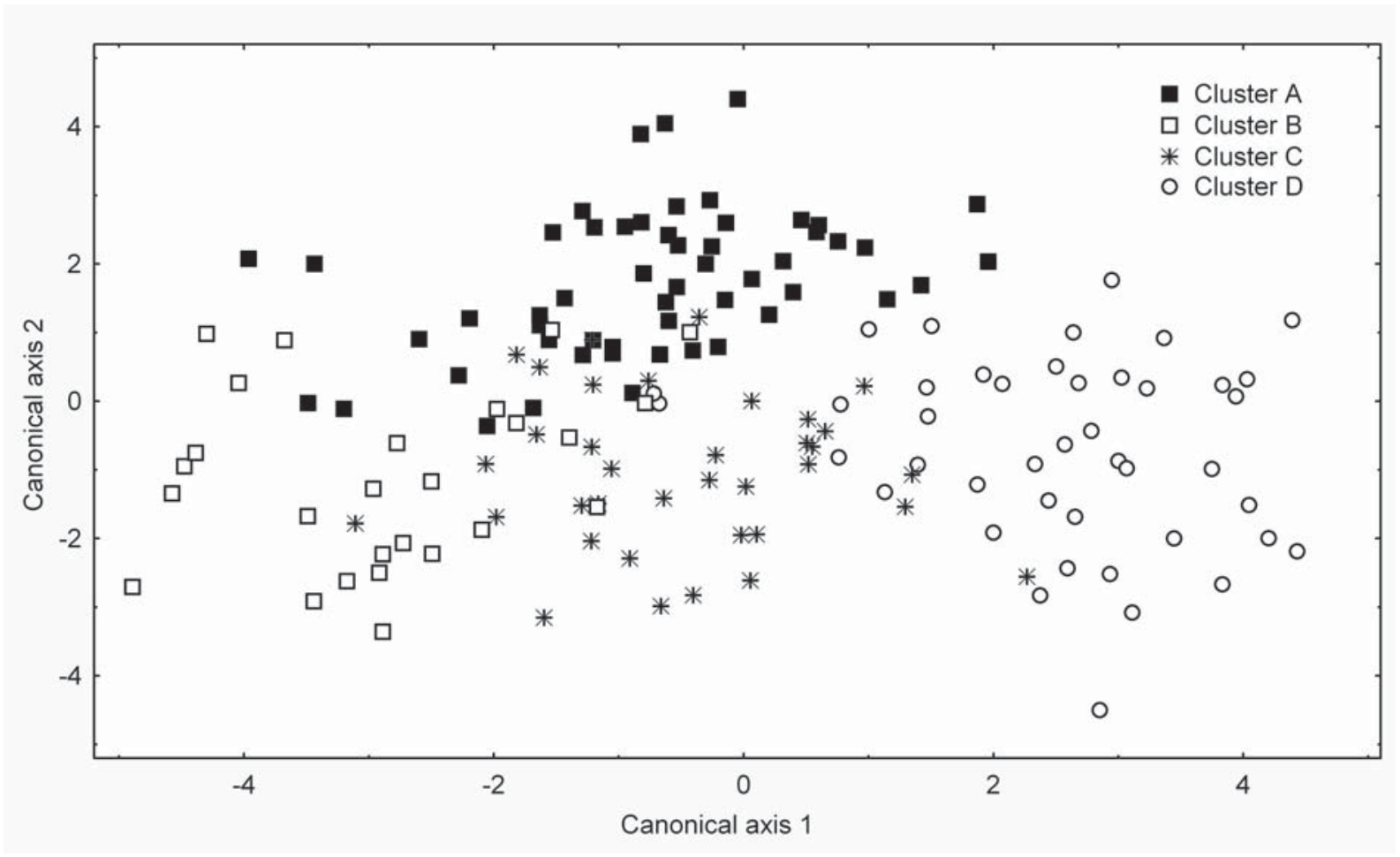

Figure 2. Distribution of Microtus middendorffii s.l. and M. gromovi specimens in the canonical hyperspace calculated based on between-sample differences. Symbols categories correspond to clusters from Fig. 1.

In 17 cases out of 44 , the posterior probability of attribution to one of the four classes $(\mathrm{A}, \mathrm{B}, \mathrm{C}, \mathrm{D})$ is bigger than $90 \%$. Five of them are dubious from the geographical viewpoint. Nine specimens demonstrates a maximal posterior probability less than $60 \%$.

The evolutionary model selected for COI corresponds to J2 (Jobb, 2008) with gamma $(\mathrm{G}=0.1235)$ distributed rates across sites and can be described in the following parameters. Base frequencies are: $\mathrm{T}=0.2637$; $\mathrm{C}=0.2923 ; \mathrm{A}=0.2695 ; \mathrm{G}=0.1744$. The probabilities of base substitutions: $\mathrm{TC}=0.2733$; $\mathrm{TA}=\mathrm{CA}=0.0173$; $\mathrm{TG}=$ $\mathrm{CG}=0.0019 ; \mathrm{AG}=0.6883$. One hundred thirty one sites are variable within the analyzed fragment, among them 51 sites are variable within $M$. middendorffii s.l.

The ML tree is shown at the Fig. 4. The representatives of $M$. middendorffii s.1., M. mongolicus, and $M$. gromovi constitute a well supported clade, where $M$. gromovi occupies a basal position. There are two major clades inside $M$. middendorffii s.l. The first includes animals from the Polar Ural Mts and Yamal Peninsula, the second one houses all the rest. The last group in its part includes four minor groups which form two clades with weak bootstrap support. The ML distances between samples are listed in the Tab. 1.

\section{Discussion}

The studied sample is well structured both morphologically and genetically. Obviously, this structure is more complicated than it was supposed in the abovementioned discussion on the status of middendorffii and hyperboreus. It should be noted that, the composition of morphological and genetical groups is consistent. However the ranks of differences between the same groups in morphological and genetical approaches do not correlate. Generally, the position of specimens in the space of canonical axes and poor predictive ability of posterior probabilities indicate on low level of morphological distinctions within the group under study.

The representatives of $M$. gromovi form distant isolated clade in our study, which is in agreement with results on another mitochondrial gene (Bannikova et al., 2010). In the morphological analysis, M. gromovi corresonds to cluster A. It includes samples from Chumikan and Ayan that were earlier identified as representatives of this species (Frisman et al., 2009; Bannikova et al., 2010). The cluster A is fully within the morphological variation of studied sample.

Thus, as follows from our results, the voles $M$. gromovi morphologically are very similar with the group M. middendorffii s.l. It noteworthy that I.S. Poljakov (1881) identified the specimen from Ayan as M. middendorffii. Both the initial assignment (Vorontsov et al., 1988) and further comparison (Sheremetyeva et al., 2008; Frisman et al., 2009) of M. gromovi with a morphologically distant species $M$. maximowiczii could be regarded as misunderstanding based on the similarity of chromosome numbers. 

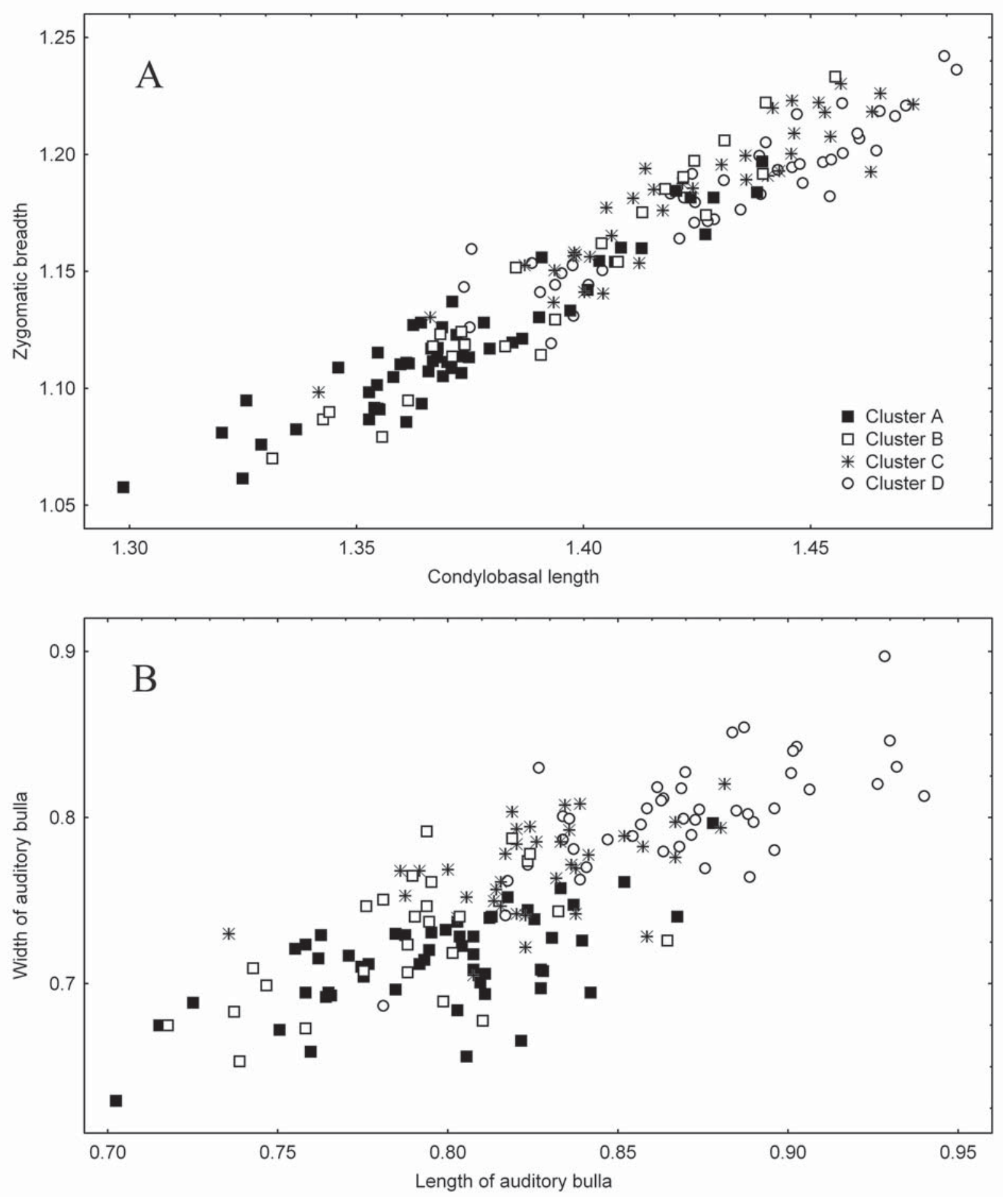

Figure 3. Distribution of Microtus middendorffii s.l. and M. gromovi specimens in the plane constituted by cranial features. The axes are in common logarithm scale. Symbols categories correspond to clusters from Fig. 1.

The variation of $M$. middendorffii s.l. demonstrates the existence of several groups. The voles inhabiting the Polar Ural Mts and Yamal Peninsula display strong genetical isolation. It is also well separated morphologically (cluster B). Obviously, this group has a taxonomic rank not lower than races middendorffii sensu stricto or hyperboreus. The name M. m. ryphaeus Heptner, 1948 is considered as the senior synonym for the voles from the area under discussion. Thus, this name could be assigned to 


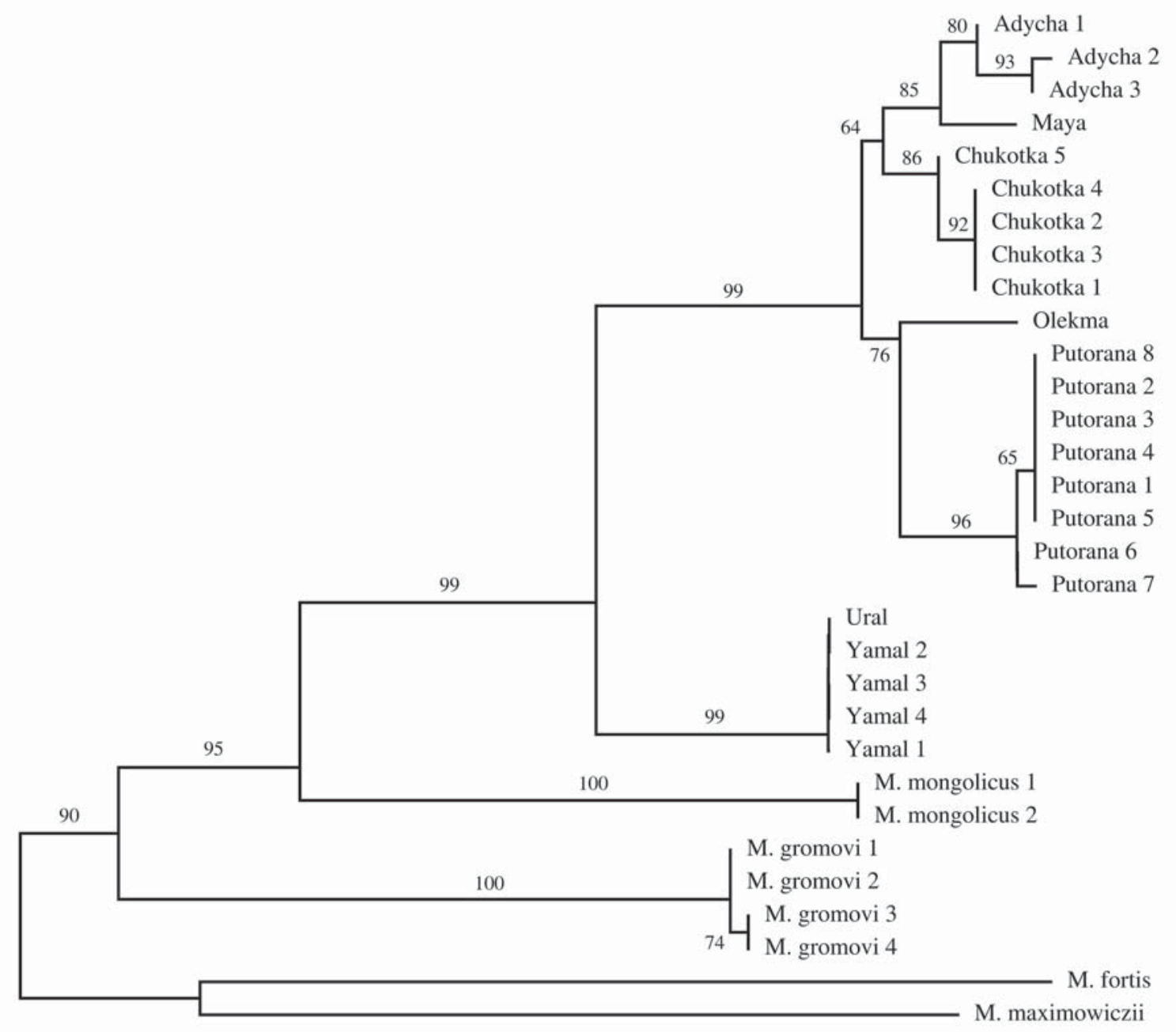

\begin{tabular}{lllll}
\hline 0.0 & 0.02 & 0.04 & 0.06 & 0.08
\end{tabular}

Figure 4. Maximum-likelihood tree of Microtus specimens constructed for cytochrome C oxidase 1st subunit. Numbers on branches indicate bootstrap support; values less than 60 are not shown. For explanations of taxa labels, refer to Appendix II.

voles from the Polar Ural Mts and Yamal Peninsula prior to a special study.

Genetical differences between middendorffii s.s. (Taimyr Peninsula) and hyperboreus s.s. (basin of Adycha River) are notably lower as compared to the distance between them and $M . m$. ryphaeus. Morphologically these two races (clusters $\mathrm{C}$ and D) differ well in the scale of present study.

Our results suggest that the range of hyperboreus race covers not only the basin of Adycha River, but Verkhoyansk Range, lower Maya River basin, upper Kolyma basin, and Omolon basin.

The samples constituting the race of middendorffii s.s. occupy Taimyr Peninsula and Putorana Plateau.
Geographically consistent pattern of specimens' arrangement into morphological clusters is disturbed by the inclusion of the sample from Baidaratskaya Bay into the race under discussion instead of $M$. m. ryphae$u s$ as it is expected from its geographical position. This phenomenon requires additional investigation. If subsequently supported, it may infer a sympatric or parapatric distribution of middendorffii and ryphaeus in the west of the range.

Two morphological samples ("Stokovy", "Lukunskaya") are distant from all groups, although, their positions on the tree unite them with geographically nearest cluster. However, the sample from Kochechum River is morphologically distinct from all other voles, 
Table 1. Average genetic ML distances (\%) between samples in analysis. For samples designation see Appendix II.

\begin{tabular}{|l|c|c|c|c|c|c|c|c|c|c|}
\hline & Maya & Chukotka & Adycha & Olekma & Putorana & $\begin{array}{c}\text { Yamal+ } \\
\text { Ural }\end{array}$ & gromovi & $\begin{array}{c}\text { mongo- } \\
\text { licus }\end{array}$ & $\begin{array}{c}\text { maximo- } \\
\text { wiczii }\end{array}$ & fortis \\
\hline Maya & 0 & & & & & & & & & \\
\hline Chukotka & 1.9 & 0 & & & & & & & & \\
\hline Adycha & 1.4 & 2.0 & 0 & & & & & & & \\
\hline Olekma & 2.7 & 2.3 & 2.8 & 0 & & & & & & \\
\hline Putorana & 2.9 & 2.5 & 2.9 & 2.2 & 0 & & & & & \\
\hline Yamal+Ural & 5.8 & 5.4 & 5.9 & 5.8 & 6.0 & 0 & & & & \\
\hline gromovi & 13.5 & 13.1 & 13.6 & 13.5 & 13.7 & 11.9 & 0 & & & \\
\hline mongolicus & 11.4 & 10.9 & 11.4 & 11.4 & 11.5 & 9.7 & 12.1 & 0 & & \\
\hline maximowiczii & 17.2 & 16.8 & 17.3 & 17.2 & 17.4 & 15.6 & 14.8 & 15.8 & 0 & \\
\hline fortis & 18.1 & 17.6 & 18.1 & 18.1 & 18.2 & 16.4 & 15.6 & 16.7 & 14.3 & 0 \\
\hline
\end{tabular}

therefore it is impossible to attribute it to one of the clusters.

It should be noted that, according to genetical results, voles from Chukot Peninsula could be placed in the race hyperboreus. Similarly, the specimen from Olekma River could be attributed to the middendorffii race. However, both these groupings demonstrate a weak bootstrap support and large ML distances segregating samples under discussion with corresponding races. We have only a few skulls in both cases, so it is impossible in the frame of our methods to discuss the degree of their morphological similarity or isolation.

Summing up this part of the study, we can state that the taxonomic pattern inside $M$. middendorffii is far from final description. It is quite probable that the pattern described here is somewhat biased by the abundance of material. Indeed, there is no doubt of the three taxa existence: $M . m$. middendorffii, M. m. hyperboreus and $M . m$. ryphaeus. At the same time, a number of local samples, based on a few specimens only, warrant a rank, similar to one of the first two taxa. These samples are from Kochechum River, Chukot Peninsula, and Olekma River. It is very probably, thus, that variation of $M$. middendorffii corresponds to a pattern of polytypic species with numerous local races. More studies are needed to elucidate this issue.

Another question, which is difficult to avoid, concerns the species/subspecies taxonomic rank of observed taxa. From morphological point of view, the degree of similarity between them is very high. They are also similar to another species, M. gromovi. Therefore, there is no grounds for a "search for separate species". In genetic approach we see quite low difference between $M . m$. middendorffii and $M . m$. hyperboreus. So there are no reasons for further discussion of full species rank of these two taxa. Quite different is the issue of $M . m$. ryphaeus. The genetic distance between this taxon and other forms of $M$. middendorffii is too small for a species rank in showing "accelerated molecular evolution" of Microtus voles (Bannikova et al., 2010). If, however, the clustering of voles from Baidaratskaya Bay with $M . m$. middendorffii reflects an affin- ity, rather than an error of the technique, this point will need a reconsideration.

Let us take up a reliability of cranial characters for determinations of races. Different authors, regardless of preferred taxa composition, proposed cranial features to descriminate between $M . m$. middendorffii and M. m. hyperboreus. These features included elongated or rounded shape of auditory bullae, zygomatic breadth, skull length, and development of skull crests (Ognev, 1950; Vinogradov \& Gromov, 1952; Krivosheev, 1971; Pozdnyakov et al., 1998; Litvinov, 2001). It should be, however, kept in mind that both the shape of auditory bullae and zygomatic breadth, length of the skull, and crests development are age-dependent. Young voles show rounded bullae and relatively small zygomatic breadth. Thus, the identifying voles on the basis of skull or bullae shape involves the additional risk to confuse age and taxonomic variation. For example, zygomatic breadth and skull length demonstrate complete overlapping between the taxa (Fig. 3). The bullae shape (proportion of length to width) shows continuous linear row of variation. The largest bullae are characteristic for $M$. m. hyperboreus (Fig. 3), as was also postulated by previous authors.

To compare our conclusions with previously published results, it is necessary to analyse the taxonomic composition in these studies. The majority of authors included the voles from the Polar Ural Mts and Yamal Peninsula into the taxon middendorffii (Ognev, 1950; Vinogradov \& Gromov, 1952; Gileva, 1972; Pokrovskiy et al., 1975; Gromov \& Polyakov, 1977). The sample from the Yama River (included in this study in $M$. gromovi) was considered within the taxon hyperboreus (Yudin et al., 1976). A number of authors included specimens from the southern Taimyr (Dudypta River) into the race hyperboreus (Ognev, 1950; Vinogradov \& Gromov, 1952; Gromov \& Polyakov, 1977). The Taimyr sample was analysed in our study and, within its frame, unambiguously belongs to middendorffii.

The data on free hybridization in captivity, given as a strong argument to uniting the taxa middendorffii and hyperboreus by some authors (Pokrovskiy et al., 1975), 
were related to taxa $M . m$. middendorffii and $M . m$. ryphaeus (at least to the Yamal population) (Volpert \& Shadrina, 2002). It is these races that shawed the similarity in karyotypes (Gileva, 1972). The difference in the location and abundance of nucleolar organizer was shown for the representatives of $M$. m. middendorffii and M. m. hyperboreus (Meyer et al., 1996).

The concept of northern lowlands from the Yana River to the Kolyma River inhabited by middendorffii, whereas the range of hyperboreus occurring either more to the south or at higher altitudes, can be quite frequently met in the literature (Vinogradov \& Gromov, 1952; Krivosheev, 1971; Gromov \& Polyakov, 1977; Meyer et al., 1996; Pozdnyakov et al., 1998; Litvinov, 2001; Volpert \& Shadrina, 2002). This viewpoint has been illustrated by quantitative data (Pozdnyakov et al., 1998; Litvinov, 2001). We had no data on voles from the lower stream of the Kolyma and Indigirka rivers which showed maximal morphological divergence from other voles (Pozdnyakov et al., 1998; Litvinov, 2001). Thus we could not evaluate the correspondence between taxa in the cited paper and those studied in the present study. The future data on this issue will give an important progress in resolving the taxonomy of Middendorff's vole.

Along with recent faunistic records (Boyeskorov et al., 1993; Dokuchaev \& Dorogoy, 2005; Abramson et al., 2009), our results notably change the concept of the range of $M$. middendorffii. In addition to the southward and eastward expansion of the known range, worth noting is investigation of several particular parts of the range. The spatial contact between the races $M . m$. middendorffii and $M . m$. ryphaeus; $M$. m. hyperboreus and $M$. gromovi are of the major interest. Another point is the identification of Middendorff's vole in the remote regions, as the mouth of Podkamennaya Tunguska, Olekma, and Maya Rivers. All these records likely indicate the occurrence of voles of this group throughout the major part of Siberia.

The last point we want to discuss is the topology of the genetic tree as regards the inter-species relationships. The relative positions of $M$. middendorffii, $M$. gromovi and $M$. mongolicus on the tree remained unclear after the previous study (Bannikova et al., 2010). We used another mitochondrial gene, and obtained the good bootstrap support for the branching pattern of these species. Thus, the splitting of $M$. gromovi is basal relative to the divergence of $M$. middendorffii and $M$. mongolicus. At the same time, from craniometrical point of view, the pair of species $M$. middendorffii and M. gromovi is hardly distinguishable.

ACKNOWLEDGEMENTS. We thank F.N. Golenishchev, G.I. Baranova, A.A. Pozdnyakov, N.V. Lopatina, A.S. Tesakov, Yu.N. Litvinov, Yu.I. Bukin, I.M. Okhlopkov, V.M. Safronov, Ya.L. Volpert, A.A. Romanov, S.V. Rupasov, S.Yu. Bodrov, T.V. Petrova, E.N. Rodchenkova. The work was financially supported by RFBR (09-04-00283, 09-04-01330, 09-04-00035),
National Geographic Society (8804-10) and Programms of RAS "Biodiversity and dynamics of gene pools" and "Biosphere origin and Evolution". Primer combination was developed by A.Yu. Kostygov, using previous data (Ivanova et al., 2007).

Analyses of COI were partly carried out at the Canadian Centre of DNA Barcoding, Biodiversity Institute of Ontario, University of Guelph and supported by grants to Paul D.N. Hebert from the Gordon and Betty Moore Foundation, Genome Canada through the Ontario Genomics Institute, the Canada Foundation for Innovation, the Ontario Innovation Trust, and the Natural Sciences and Engineering Research Council of Canada. We thank Paul D.N. Hebert for administrative support.

\section{References}

Abramson N.I., Abramov A.V., Baranova G.I. \& Petrova T.V. 2009. DNA barcoding of Palaearctic rodents reveal new records of species and numerous misidentifications // Abstracts of the 10-th International Mammalogical Congress. Mendoza, Argentina, 9 - 14 August 2009. P.44.

Bannikova A.A., Lebedev V.S., Lissovsky A.A., Matrosova V., Abramson N.I., Obolenskaya E.V. \& Tesakov A.S. 2010. Molecular phylogeny and evolution of the Asian lineage of vole genus Microtus (Rodentia: Arvicolinae) inferred from mitochondrial cytochrome b sequence // Biological Journal of the Linnean Society. Vol.99. P.595613.

Boyeskorov G.G., Yegorov N.G. \& Revin Yu.V. 1993. Microtus hyperboreus (Mammalia, Rodentia) in South-Eastern Yakutia // Vestnik Zoologii. No.2. P.72-74 [in Russian].

Burnaby T.P. 1966. Growth-invariant discriminant functions and generalized distances // Biometrics. Vol.22. P.96110.

Dokuchaev N.E. \& Dorogoy I.V. 2005. New records of Microtus hyperboreus Vinogradov, 1933 (Rodentia, Arvicolidae) in Chukotka // Russian Journal of Theriology. Vol.4. No.1. P.75-77.

Frisman L.V, Korobitsyna K.V., Kartavtseva I.V, Sheremetyeva I.N. \& Voyta L.L. 2009. Voles (Microtus Schrank, 1798) of the Russian Far East: allozymic and karyological divergence // Russian Journal of Genetics. Vol.45. No.6. P.707-714

Gileva E.A. 1972. [Chromosomal polymorphism in two related taxa of subarctic voles (North Siberian vole and Middendorff's vole)] // Doklady AN SSSR. Vol.203. No.3. P.689-692 [in Russian].

Gromov I.M. \& Polyakov I.Ya. 1977. [Fauna of the USSR, Voles (Microtinae): Mammals]. Leningrad: Izdatel'stvo Nauka. Vol.3. No.8. 504 p. [in Russian]

Ivanova N.V., Zemlak T.S., Hanner R.H. \& Hebert P.D.N. 2007. Universal primer cocktails for fish DNA barcoding // Molecular Ecology Notes. Vol.7. P.544-548.

Jobb G. 2008. TREEFINDER, June 2008. Distributed by the author. Available at: http://www.treefinder.de

Krivosheev V.G. 1971. [Microtus middendorffii Poljakov (1881) and Microtus hyperboreus Vinogradov (1933)] // 
Tavrovskiy V.A. (eds.) [Mammals of Yakutiya]. Moskva: Izdatel'stvo Nauka. P.332-342 [in Russian].

Lissovsky A.A. \& Obolenskaya E.V. 2010. [Structure of craniometric variation of root vole (Microtus oeconomus, Rodentia)]// Zoologicheskii Zhurnal. Vol.89. No.6. P.1-5 [in Russian, with English summary].

Litvinov Yu.N. 2001. [Communities and populations of small mammals in Siberian ecosystems]. Novosibirsk: Izdatel'stvo TSERIS. 128 p. [in Russian]

Marcus L.F. 1993. Some aspects of multivariate statistics for morphometrics // Marcus L.F., Bello E. \& García-Valdecasas A. (eds.). Contributions to Morphometrics. Madrid: C.S.I.C. P.95-130.

Meyer M.N., Golenishchev F.N., Radjably S.I. \& Sablina O.V. 1996. [Gray voles (subgenus Microtus Schrank) of Russia and adjacent territories]. Trudy Zoologicheskogo Instituta RAN. Vol.232. St Petersburg: Russian Academy of Sciences. 320 p. [in Russian]

Ognev S.I. 1950. [The Mammals of the USSR and adjacent territories. Rodents]. Vol.7. Moskva-Leningrad: Izdatel'stvo AN SSSR. 706 p. [in Russian]

Pokrovskii A.V., Vasil'eva A.V. \& Lobanova N.A. 1975 [Comparative study of Middendorf's Vole, North Siberian Vole and their hybrids] // Population variation in animals. Sverdlovsk: Izdatel'stvo AN SSSR, Ural'skii centr. P.39-62 [in Russian].

Poljakov I.S. 1881. [Taxonomic review of Voles, living in Siberia] // Zapiski Imperatorskoi Akademii Nauk. Vol.39. Addendum 2. St Petersburg: Imperatorskaya Akademiya Nauk. 92 p. [in Russian]

Pozdnyakov A.A., Litvinov Yu.N. \& Vol'pert Ya.L. 1998. [Distribution and intraspecific diversity of two related species of northern voles] // Sibirskii Ekologicheskii Zhurnal. Vol.3-4. P.337-345 [in Russian].

Sheremetyeva I.N., Kartavtseva I.V., Voyta L.L., Kryukov A.P. \& Haring E. 2009. Morphometric analysis of intraspecific variation in Microtus maximowiczii (Rodentia, Cricetidae) in relation to chromosomal differentiation with reinstatement of Microtus gromovi Vorontsov et al. 1988, stat. nov. // Journal of Zoological Systematics and Evolutionary Research. Vol.47. P.42-48.

StatSoft Inc. 2007. STATISTICA (data analysis software system), version 8.0. www.statsoft.com.

Tamura K. Dudley J., Nei M. \& Kumar S. 2007. MEGA4: molecular evolutionary genetics analysis (MEGA) software version 4.0. // Molecular Biology and Evolution. Vol.24. P.1596-1599.

Yudin B.S., Krivosheev V.G. \& Belyaev V.G. 1976. [The Small Mammals of the North of Far East]. Novosibirsk: Izdatel'stvo Nauka. 269 p. [in Russian]

Vinogradov B.S. 1933. [Mammals of USSR. Rodents]. Leningrad: Izdatel'stvo AN SSSR. 87 p. [in Russian]

Vinogradov B.S. \& Gromov I.M. 1952. [The Rodents of Fauna of USSR]. Moskva-Leningrad: Izdatel'stvo AN SSSR. 298 p. [in Russian]

Vol'pert Ya.L. \& Shadrina E.G. 2002. [The small Mammals of the North-East Siberia]. Novosibirsk: Izdatel'stvo Nauka. 246 p. [in Russian]

Vorontsov N.N., Boeskorov G.G., Lyapunova E.A. \& Revin Yu.V. 1988. [A New Chromosome Form and Variation in Microtus maximowiczii (Rodentia, Cricetidae)] // Zoologicheskii Zhurnal. Vol.67. No.2. P.205-213 [in Russian, with English summary].

Appendix I. The list of specimens used in morphometrical analysis. Information is in the following order: the name of the sample in quotes (only for the samples used in cluster analysis), locality and geographical coordinates, museum, the specimens number in parenthesis.

«KrasnK»—-Yamalo-Nenetskiy Autonomous District, Polar Ural Mts., railway station Krasniy Kamen, 66.55 N, 65.45 E, IPAE (12);

«Baidar» - Yamalo-Nenetskiy Autonomous District, south of Baidaratskaya Guba Bay, 68.2 N, 67.2 E, IPAE (6); «Schuchya» - Yamalo-Nenetskiy Autonomous District, south of Yamal Peninsula, middle part of Schuchya River, 67.365 N, 68.708 E, ZMMU (8); (7); «Uribey» - Yamalo-Nenetskiy Autonomous District, center of Yamal Peninsula, Yuribey River, 68.48 N, 71.18 E, IPAE

«Norilsk» - Krasnoyarskiy Kray, vicinities of Norilsk, 69.371 N, 88.397 E, ISEA (4);

«Hantay» - Krasnoyarskiy Kray, Putorana Plateau, Khantayskoe Lake, 68.267 N, 90.796 E, ISEA (7);

«Keta» - Krasnoyarskiy Kray, Putorana Plateau, Keta Lake, 68.834 N, 91.632 E, ZIN (8);

«Gusinye»- Krasnoyarskiy Kray, Putorana Plateau, Gusiniye Lakes, 68.3 N, 93.6 E, ZMMU (7);

«Dudypta» - Krasnoyarskiy Kray, south-east of Taimyr Peninsula, Dudypta River near mouth of Kamennaya River,

71.443 N, 94.104 E, ZMMU (5);

«Kochechum» - Krasnoyarskiy Kray, Turukhanskiy District, vicinities of Tola village, Kochechum River, 64.542 N, 100.222 E, ZIN (7);

«Lukunskaya» - Krasnoyarskiy Kray, Lukunskaya River — right tributary of Khatanga River, 72.529 N, 105.166 E,

ISEA (5);

«Omoloy» - Republic of Yakutia-Sakha, Bulunskiy District, Omoloy River, 70.696 N, 133.265 E, ZIN (10);

«Chumikan» - Khabarovskiy Kray, Uda River, 25 km from Chumikan, 54.61 N, 135.01 E, ZMMU (27);

«Adycha» - Republic of Yakutia-Sakha, Verkhoyanskiy District, Adycha River, 67.532 N, 135.436 E, ZIN (6);

«Betenkes» - Republic of Yakutia-Sakha, Verkhoyanskiy District, Adycha River, Betenkes village, 67.579 N, 135.672

E, ZIN (9);

«Ayan» - Khabarovskiy Kray, Ayano-Mayskiy District, Ayan Village, 56.464 N, 138.161 E, ZMMU (21);

«Stokovy» - Magadan Region, Kulu River basin, Stokovoye, 61.848 N, 147.662 E, IBPN (6);

«Yama» - Magadan Region, Maymadzhinskiy Range, upper Yama River, 60.755 N, 151.786 E, ZMMU (9); 
«Kolyma» - Magadan Region, Srednekanskiy District, right bank of Kolyma River, 62.591 N, 152.379 E, ZMMU (4); «Omolon» - Chukot Autonomous Province, vicinities of Omolon village, 65.237 N, 160.555 E, ZIN (10); «Kegali» — Magadan Region, Omolon River basin, near Kegali village, 64.358 N, 161.955 E, ISEA (5); Republic of Komi, 134 km from Seyda railway station, 67.239 N, 63.043 E, ZMMU (1);

Yamalo-Nenetskiy Autonomous District, Eastern slope of Polar Ural Range, upper Sukhaya Synya River, 65.559 N, 63.073 E, ZIN (2);

Yamalo-Nenetskiy Autonomous District, Polar Ural, $60 \mathrm{~km}$ by railway from Labytnangi, 66.922 N, 65.74 E, ZMMU (1); Yamalo-Nenetskiy Autonomous District, $12 \mathrm{~km}$ to NW from Labytnangi, 66.734 N, 66.266 E, ZIN (2);

Yamalo-Nenetskiy Autonomous District, south of Yamal Peninsula, Longotyugan River, 66.5 N, 67.44 E, IPAE (3); Yamalo-Nenetskiy Autonomous District, north-west part of Yamal Peninsula, Sedoty-yakha River, 69.584 N, 67.699 E, ZIN (1);

Yamalo-Nenetskiy Autonomous District, south of Yamal Peninsula, vicinities of Schuchye village, 67.365 N, 68.708 E, ZMMU (2);

Yamalo-Nenetskiy Autonomous District, Krasnoselkupskiy District, Taz River, Tserkovenskoye village, 65.51 N, 82.133

E, ZIN (1);

Krasnoyarskiy Kray, vicinities of Norilsk, $1 \mathrm{~km}$ to the S from Nadezhda airport, 69.308 N, 87.981 E, ZIN (1);

Krasnoyarskiy Kray, Turuchanskiy District, Mirnoe research station, 62.37203 N, 89.061899 E, ZMMU (1);

Krasnoyarskiy Kray, south-east of Taimyr Peninsula, Kresty village near mouth of Dudypta

River, 70.853 N, 89.924 E, ZIN (1);

Krasnoyarskiy Kray, Putorana Plateau, near mouth of Irekteken River, 68.3 N, 93.8 E, ZMMU (3);

Republic of Yakutia-Sakha, Olenek River near mouth of Pur River, 71.809 N, 123.58 E, ZIN (2);

Republic of Yakutia-Sakha, lower part of Lena River, approximate coordinates 70.828 N, 127 E, ZIN (1); (1);

Republic of Yakutia-Sakha, Verkhoyanskiy District, Yana River 50 km lower Verkhoyansk, 67.565 N, 134.034 E, ZIN

Republic of Yakutia-Sakha, Ust-Mayskiy District, mouth of Chabda River - left tributary of Maya River, 59.776 N, 134.812 E, ZMMU (1);

Republic of Yakutia-Sakha, Verkhoyanskiy District, Adycha River, Ust-Charky, 66.764 N, 136.601 E, ZIN (1);

Khabarovskiy Kray, Ul’banskiy Bay, Itkan River, 53.529 N, 137.644 E, ZMMU (1);

Republic of Yakutia-Sakha, Oymyakon Plateau, 100 km from Tas-Kys-Tabyt Range, 63.29 N, 143.06 E, ZMMU (1);

Republic of Yakutia-Sakha, Allaikhovskiy District, Berelekh River valley, 70.979 N, 148.979 E, ZMMU (1);

Chukot Autonomous Province, vicinities of Anadyr' airport, 64.807 N, 177.584 E, ZMMU (1);

Magadan Region, vicinities of Omsukchan, 62.531 N, 155.848 E, ZIN (1);

Magadan Region, Elikchanskiye Lakes, 60.755 N, 151.786 E, IBPN (1);

Republic of Yakutia-Sakha, Nizhnekolymskiy District, upper part of Stadukhinskaya channel, 68.663 N, 161.152 E, ISEA (1);

Koryakskiy Autonomous District, Shayboveem River, tributary of Pehzhina River, 64.102 N, 164.489 E, ZMMU (1);

Chukot Autonomous Province, Sredniy Kaiemravaam River - the left tributary of Mechkereva River, 66.823 N, 169.556

E, IBPN (2);

Chukot Autonomous Province, vicinities of Pevek, 69.681 N, 170.411 E, ZMMU (1);

Chukot Autonomous Province, Chaunskiy District, upper Keveem River, Mayskiy, 68.966 N, 173.7 E, IBPN (2).

Appendix II. The list of specimens used in genetic analysis. The Genebank/BOLD ID-s are shown.

\begin{tabular}{|c|c|c|c|}
\hline Label & Museum ID & ID & Locality \\
\hline Maya & ZMMU S-183385 & $\begin{array}{l}\text { HM137743/ } \\
\text { MEP162-08 }\end{array}$ & $\begin{array}{l}\text { Republic of Yakutia-Sakha, Ust-Mayskiy District, mouth } \\
\text { of Chabda River - left tributary of Maya River, } 59.776 \\
\text { N, } 134.812 \text { E }\end{array}$ \\
\hline Putorana 1 & ZMMU S-181778 & $\begin{array}{l}\text { HM137750/ } \\
\text { SKMZM521-08 }\end{array}$ & $\begin{array}{l}\text { Krasnoyarskiy Kray, Putorana Plateau, Kureyka River } \\
68.3 \text { N, 93.6 E }\end{array}$ \\
\hline Putorana 2 & ZMMU S-181780 & $\begin{array}{l}\text { HM137749/ } \\
\text { SKMZM522-08 }\end{array}$ & $\begin{array}{l}\text { Krasnoyarskiy Kray, Putorana Plateau, Kureyka River } \\
68.3 \text { N, 93.6 E }\end{array}$ \\
\hline Putorana 3 & ZMMU S-181792 & $\begin{array}{l}\text { HM137748/ } \\
\text { SKMZM523-08 }\end{array}$ & $\begin{array}{l}\text { Krasnoyarskiy Kray, Putorana Plateau, Kureyka River } \\
68.3 \text { N, 93.6 E }\end{array}$ \\
\hline Putorana 4 & ZMMU S-181791 & $\begin{array}{l}\text { HM137747/ } \\
\text { SKMZM524-08 }\end{array}$ & $\begin{array}{l}\text { Krasnoyarskiy Kray, Putorana Plateau, Kureyka River } \\
68.3 \text { N, 93.6 E }\end{array}$ \\
\hline Putorana 5 & ZMMU S-181779 & $\begin{array}{l}\text { HM137746/ } \\
\text { SKMZM525-08 }\end{array}$ & $\begin{array}{l}\text { Krasnoyarskiy Kray, Putorana Plateau, Kureyka River } \\
68.3 \text { N, 93.6 E }\end{array}$ \\
\hline Putorana 6 & ZMMU S-181794 & $\begin{array}{l}\text { HM137745/ } \\
\text { SKMZM526-08 }\end{array}$ & $\begin{array}{l}\text { Krasnoyarskiy Kray, Putorana Plateau, Kureyka River } \\
68.3 \text { N, 93.6 E }\end{array}$ \\
\hline Putorana 7 & ZMMU S-181789 & $\begin{array}{l}\text { HM137744/ } \\
\text { SKMZM527-08 }\end{array}$ & $\begin{array}{l}\text { Krasnoyarskiy Kray, Putorana Plateau, Kureyka River } \\
68.3 \text { N, 93.6 E }\end{array}$ \\
\hline Putorana 8 & ZMMU S-181782 & $\begin{array}{l}\text { HM137751/ } \\
\text { SKMZM239-07 }\end{array}$ & $\begin{array}{l}\text { Krasnoyarskiy Kray, Putorana Plateau, Kureyka River } \\
68.3 \text { N, 93.6 E }\end{array}$ \\
\hline
\end{tabular}


Appendix II (continued).

\begin{tabular}{|c|c|c|c|}
\hline Label & Museum ID & ID & Locality \\
\hline Yamal 1 & - & $\begin{array}{l}\text { HM137742/ } \\
\text { SKMZM873-09 }\end{array}$ & $\begin{array}{l}\text { Yamal-Nenets Autonomous Province, Yamal Peninsula, } \\
\text { right bank of the Yerkata-Yakha river, } 68.2 \mathrm{~N}, 68.8 \mathrm{E}\end{array}$ \\
\hline Yamal 2 & - & $\begin{array}{l}\text { HM137740/ } \\
\text { SKMZM875-09 }\end{array}$ & $\begin{array}{l}\text { Yamal-Nenets Autonomous Province, Yamal Peninsula, } \\
\text { right bank of the Yerkata-Yakha river, } 68.2 \mathrm{~N}, 68.8 \mathrm{E}\end{array}$ \\
\hline Yamal 3 & - & $\begin{array}{l}\text { HM137739/ } \\
\text { SKMZM876-09 }\end{array}$ & $\begin{array}{l}\text { Yamal-Nenets Autonomous Province, Yamal Peninsula, } \\
\text { right bank of the Yerkata-Yakha river, 68.2 N, 68.8 E }\end{array}$ \\
\hline Yamal 4 & - & $\begin{array}{l}\text { HM137738/ } \\
\text { SKMZM877-09 }\end{array}$ & $\begin{array}{l}\text { Yamal-Nenets Autonomous Province, Yamal Peninsula, } \\
\text { right bank of the Yerkata-Yakha river, } 68.2 \mathrm{~N}, 68.8 \mathrm{E}\end{array}$ \\
\hline Chukotka 1 & IBPN 6034 & $\begin{array}{l}\text { HM137731/ } \\
\text { NAZIM446-08 }\end{array}$ & $\begin{array}{l}\text { Chukot Autonomous Province, Sredniy Kaiemravaam } \\
\text { River - the left tributary of Mechkereva River, } 66.9 \text { N, } \\
\text { 169.6 E }\end{array}$ \\
\hline Chukotka 2 & IBPN 6033 & $\begin{array}{l}\text { HM137732/ } \\
\text { NAZIM445-08 }\end{array}$ & $\begin{array}{l}\text { Chukot Autonomous Province, Sredniy Kaiemravaam } \\
\text { River - the left tributary of Mechkereva River, } 66.9 \text { N, } \\
\text { 169.6 E }\end{array}$ \\
\hline Chukotka 3 & IBPN 6032 & $\begin{array}{l}\text { HM137733/ } \\
\text { NAZIM444-08 }\end{array}$ & $\begin{array}{l}\text { Chukot Autonomous Province, Sredniy Kaiemravaam } \\
\text { River - the left tributary of Mechkereva River, } 66.9 \text { N, } \\
\text { 169.6 E }\end{array}$ \\
\hline Chukotka 4 & IBPN 6031 & $\begin{array}{l}\text { HM137734/ } \\
\text { NAZIM443-08 }\end{array}$ & $\begin{array}{l}\text { Chukot Autonomous Province, Sredniy Kaiemravaam } \\
\text { River - the left tributary of Mechkereva River, } 66.9 \text { N, } \\
\text { 169.6 E }\end{array}$ \\
\hline Chukotka 5 & IBPN 6030 & $\begin{array}{l}\text { HM137735/ } \\
\text { NAZIM442-08 }\end{array}$ & $\begin{array}{l}\text { Chukot Autonomous Province, Sredniy Kaiemravaam } \\
\text { River - the left tributary of Mechkereva River, } 66.9 \mathrm{~N} \text {, } \\
169.6 \mathrm{E}\end{array}$ \\
\hline Olekma & - & $\begin{array}{l}\text { HM137736/ } \\
\text { NAZIM287-08 }\end{array}$ & $\begin{array}{l}\text { Republic of Yakutia-Sakha, Olekminskiy District, } \\
\text { vicinities of Torgo village, } 58.5 \mathrm{~N}, 119.5 \mathrm{E}\end{array}$ \\
\hline Ural & ZIN 98040 & $\begin{array}{l}\text { HM137752/ } \\
\text { NAZIM738-08 }\end{array}$ & $\begin{array}{l}\text { Yamal-Nenets Autonomous Province, Labytnangi City } \\
\text { Council, Krasniy Kamen railway station, 66.9 N, 65.7 E }\end{array}$ \\
\hline Adycha 1 & ZIN 99689 & JF723544/- & $\begin{array}{l}\text { Republic of Yakutia-Sakha, Verkhoyanskiy District, near } \\
\text { the mouth of Tuostakh River, } 67.9 \text { N, 135.5 E }\end{array}$ \\
\hline Adycha 2 & ZIN 99691 & JF723545/- & $\begin{array}{l}\text { Republic of Yakutia-Sakha, Verkhoyanskiy District, } \\
\text { vicinities of Tomtor village, } 67.1 \mathrm{~N}, 134.6 \mathrm{E}\end{array}$ \\
\hline Adycha 3 & ZIN 99707 & JF723546/- & $\begin{array}{l}\text { Republic of Yakutia-Sakha, Verkhoyanskiy District, } \\
\text { vicinities of Tomtor village, 67.2 N, 134.9 E }\end{array}$ \\
\hline M. gromovi 1 & ZMMU S-187568 & JF723547/- & $\begin{array}{l}\text { Khabarovskiy Kray, Tuguro-Chumikanskiy District, } \\
\text { Dzhangin River, 55.5 N, 134.4 E }\end{array}$ \\
\hline M. gromovi 2 & ZMMU S-187569 & JF723548/- & $\begin{array}{l}\text { Khabarovskiy Kray, Tuguro-Chumikanskiy District, } \\
\text { Dzhangin River, 55.5 N, 134.4 E }\end{array}$ \\
\hline M. gromovi 3 & ZMMU S-187545 & JF723549/- & $\begin{array}{l}\text { Khabarovskiy Kray, Ayano-Mayskiy District, Eldomu- } \\
\text { Makit River, 55.8 N, 134.2 E }\end{array}$ \\
\hline M. gromovi 4 & ZMMU S-187546 & JF723550/- & $\begin{array}{l}\text { Khabarovskiy Kray, Ayano-Mayskiy District, Eldomu- } \\
\text { Makit River, 55.8 N, 134.2 E }\end{array}$ \\
\hline M. mongolicus 1 & ZMMU S-180448 & $\begin{array}{l}\text { HM137754/ } \\
\text { SKMZM213-07 }\end{array}$ & $\begin{array}{l}\text { Chita Region, Krasnokamenskiy District, } 6 \mathrm{~km} \mathrm{~S} \text { of } \\
\text { Kuytun, 50.1 N, } 118.7 \mathrm{E}\end{array}$ \\
\hline M. mongolicus 2 & ZMMU S-180449 & $\begin{array}{l}\text { HM137753/ } \\
\text { SKMZM215-07 }\end{array}$ & $\begin{array}{l}\text { Chita Region, Krasnokamenskiy District, } 6 \mathrm{~km} \mathrm{~S} \text { of } \\
\text { Kuytun, } 50.1 \mathrm{~N}, 118.7 \mathrm{E}\end{array}$ \\
\hline M. maximowiczii & ZMMU S-178597 & $\begin{array}{l}\text { HM137737/ } \\
\text { SKMZM179-07 }\end{array}$ & $\begin{array}{l}\text { Chita Region, Kalganskiy District, vicinities of Kozlovo } \\
\text { village, } 51.2 \mathrm{~N}, 118.9 \mathrm{E}\end{array}$ \\
\hline M. fortis & ZMMU S-178587 & $\begin{array}{l}\text { HM137730/ } \\
\text { SKMZM185-07 }\end{array}$ & $\begin{array}{l}\text { Chita Region, Aleksandrovo-Zavodskiy District, upper } \\
\text { Kher-Khira River, } 50.4 \text { N, } 118.1 \text { E }\end{array}$ \\
\hline
\end{tabular}

